\title{
Commoditisation and Sustainable Management of Mithun (Bos Frontalis) In Arunachal Pradesh, North-East India
}

\author{
Dr. Otem Moyong \\ Sr. Assistant Professor, Department of commerce Rajiv Gandhi University, Itanagar
}

\begin{abstract}
Endemic to North-East India's jungles, the Mithun (Bos frontalis) is a rare bovine species. According to the 2003 livestock census, Mithun population in India is 0.28 million out of which the highest number of 1,92,000 Mithuns have been recorded in Arunachal Pradesh followed by 40,000 in Nagaland, 20,000 in Manipur and 2,000 in Mizoram.

Deeply rooted in the mythology and being an integral part of cultural life especially among the Tani Groups viz. Adi, Apatani, Galo, Nyishi and Tagin, Mithun is not only considered as one of the most important cultural resources of these tribes but also the pride of Arunachal Pradesh. Due to its inherent socio-cultural and economic dynamism, Mithun plays a multidimensional role in the tribal society of the state. The wealth of a person is often gauged by the number of Mithuns he possesses and thus determines his/her social status. The Mithun is regarded as a symbol of prestige and was traditionally used as a medium of exchange (which is still a common practice among the people residing in villages), a means to settling disputes, and as the bride price. They also provide calories and protein, and are essential part of community feasts especially during festivals and other important social occasions. Besides, Mithun is also considered as a social security during any kind of emergency in health and other household related problems etc. Yet, Mithuns are a semi domesticated animal and reared under free grazing condition.

However, over the last many years uses of Mithuns in Arunachal Pradesh are largely found to be commercial than cultural. Today, Mithun's meats are available in the market at Rs $300 \mathrm{per} \mathrm{kg}$. In fact, some of the tribal families are surviving and educating their children by selling Mithuns/meat. Further, due to limitless killing of Mithun during election and marriage ceremony, Mithun population are reducing drastically. Thus, Mithuns are found to have losing its mythological and cultural importance, in that the glory and values of Mithuns have fallen from cultural to commodity/commercial. Since, this species is considered as vulnerable to extinction, proper research and in-depth study is very much required for the sustainable management of Mithun. Thus, in the present study an attempt has been made to discuss the various socio-cultural and economic dynamics of Mithun responsible for commoditisation of Mithuns in Arunachal Pradesh as well as to formulate strategy to address the problems for sustainable management of Mithun.
\end{abstract}

Keywords: mythology, cultural resources, economic dynamism, commoditisation, sustainable management.

\section{Introduction}

The mithun (Bos frontalis) is a unique ruminant found in the hill regions of northeast India, Myanmar, Bhutan, Bangladesh, the People's Republic of China and Malaysia. In India, there are four distinct strains of mithun i.e. Arunachal strain, Manipur strain, Mizoram strain and Nagaland strain (Das, Mukharjee \& others 2011). These different strains are distinguished by their distinct physical and genetic features. According to the 2007 livestock census, highest number of mithun in the north-eastern states has been recorded in Arunachal Pradesh figuring 2,18,931 followed by 33,385 in Nagaland. Mithuns are normally found at elevations ranging from 300 to $3,000 \mathrm{~m}$ above sea level, in shrubs and forested areas.

The people of Arunachal Pradesh especially the Tani Groups viz. Adi, Apatani, Galo, Nyishi and Tagin, have been engaged in mithun rearing activities since time immemorial and therefore mithun has occupied a central position in the socio-cultural life of these indigenous communities. Though mithun is semidomesticated animal, rearing of mithun is very tough task. It is believe that a only a person with a gift can rear mithuns.

Mithun feed on forest leaves, young plants and grasses. Mithuns are normally browsers rather than grazers, eating forest leaves and young plants, instead of requiring pasture land like other bovines. In a kind of part-time domestication, mithuns have usually been "kept" by releasing them into forests for feeding during the day with or without human supervision. While some mithuns become feral and stay in the forest full-time, most communities would bring them back to the village for the night.

The Mithun is used for many purposes. As a potential source of meat, the Mithun is considered to be an efficient converter of forest biomass into valuable beef, with a daily body weight gain of $500 \mathrm{~g}$. The body weight of the adult Mithun varies from $400 \mathrm{~kg}$ to $600 \mathrm{~kg}$. The Mithun also produces superior quality milk, with 
the percentage of fat ranging from $11 \%$ to $13 \%$. The Mithun is a useful draught and pack animal, due to its surefootedness on the steep hill slopes, and it is also used as a bridal gift.

\section{Statement Of The Problem}

Deeply rooted in the mythology and being an integral part of cultural life especially among the Tani Groups, Mithun is not only considered as one of the most important cultural resources of these tribes but also the pride of Arunachal Pradesh. Due to its inherent socio-cultural and economic dynamism, Mithun plays a multidimensional role in the tribal society of the state. The wealth of a person is often gauged by the number of Mithuns he possesses and thus determines his/her social status. The Mithun is regarded as a symbol of prestige and was traditionally used as a medium of exchange (which is still a common practice among the people residing in villages), a means to settling disputes, and as the bride price/bridal gift. They also provide calories and protein, and are essential part of community feasts especially during festivals and other important social occasions. Besides, Mithun is also considered as a social security during any kind of emergency in health and other household related problems etc. Yet, Mithuns are a semi domesticated animal and reared under free grazing condition.

Essentially Mithuns are considered as a sacred animal especially among the Tani Groups and reared mainly for socio-cultural purposes ranging from sacrifices during festivals (like Solung of the Adis, Nyokum of Nyishis, Si-Donyi of Tagins, Mopin of Galos etc), settling disputes and as a bride price/bridal gift. However, over the last many years uses of mithuns in Arunachal Pradesh are largely found to be more commercial than cultural. Today, mithun's meats are available in the market at Rs 300 per $\mathrm{kg}$. In fact, some of the tribal families are surviving and educating their children by selling mithuns/ meat. Further, due to limitless killing of Mithun during election and marriage ceremony, mithun population are reducing drastically. Thus, Mithuns are found to have losing its mythological and cultural importance, in that the glory and values of Mithuns have fallen from cultural to commodity/commercial. Since, this species is considered as vulnerable to extinction, proper research and in-depth study is very much required for the sustainable management of Mithun.

In the light of above discussion an attempt has been made in the present study to highlight the various the factors responsible for commercialisation of Mithuns as well as to address the problems related to sustainable management of Mithuns in the state of Arunachal Pradesh.

\section{Objectives}

The main objectives of the study are

1. To examine the factors responsible for commoditisation of Mithun.

2. To formulate strategy to address the problems for sustainable management of Mithun.

\section{Methodology}

In order to make the study more informative, acceptable and empirical, necessary information and data were collected through primary and secondary sources by adopting judgement as well as convenience sampling technique. During the course of study ten samples respondents from all the five selected district of Arunachal Pradesh viz. Papum Pare, Lower Subansiri, Upper Subansiri, West Siang, East Siang and Upper Siang respectively. These sample respondents comprises of 22 Mithun owner, 18 village elders and 10 butchers (Mithun meat seller). In order to obtain the required information and data, direct personal interviews and indirect oral interviews was conducted with the help of well designed schedule. The interpretation and analyses of the information collected have been made by adopting quantitative and qualitative approach.

\section{Mithun Being Commoditized}

During the course of study the following have been identified as the main factors responsible for the commoditisation of Mithuns in the state of Arunachal Pradesh.

1. Medium of exchange: Traditionally Mithuns were also used as a medium of exchange (which is still a common practice among the people residing in remote villages). However after monetisation, due to inherent values in mithuns and want of money, mithun as a commodity got easily commercialised.

2. Economic dynamism: Mithun plays a multidimensional role in the tribal society of the state. The wealth of a person is often gauged by the number of Mithuns he possesses and thus determines his/her social status. The Mithun is regarded as a symbol of prestige and a means to settling disputes, as the bride price/bridal gift etc. Besides, Mithun is also considered as a social security during any kind of emergency in health and other household related problems etc. Hence, due to the economic dynamism it is observed that demand of mithun is very high in tribal society which ultimately led to commercialisation of mithuns in Arunachal Pradesh.

3. Liquidity: Due to high demand of mithun, the liquidity position of mithun is very high compared to other domestic animals. It is observed that, there is positive relationship between liquidity and 
Commoditisation And Sustainable Management Of Mithun (Bos Frontalis) In Arunachal Pradesh,

commercialisation. Such state of affairs have are found especially during the time of emergency in health and other household related problems.

4. High demand for meat: During the course of survey it has been observed that demands and preference of mithun meat are very high among the tribal people. However, unlike others (beef, pork, fish etc.), mithun meat is not readily available in the market. This state of affairs over the last couple of years has greatly caused mithun meat to enter in the commercial market.

5. Money matters: It has been found that the people in the village sells mithun more frequently for educating their children and other domestic purposes like purchase of food, utensils and cloths for household consumptions. It can be observed from the Table 1 that price of the mithuns aging 2-3 years old (Rs 35,000 to 45,000) and 3-4 years (Rs 45,000 to 55,000) are found to be highest in Papumpare and Upper Subansiri districts. Whereas, the mithuns of same age as above are available at Rs 18,000 to 25,000 and Rs 25,000 to 35,000 in East Siang and Upper Siang Districts.

Table 1 Showing Market Price of Mithun in the selected Districts of Arunachal Pradesh (Market price as on 28.12.11)

\begin{tabular}{|lll|}
\hline Name of District & $\begin{array}{l}\text { Mithuns } \\
\text { (in years) }\end{array}$ & $\begin{array}{l}\text { Price range } \\
\text { (in '000 rupee) }\end{array}$ \\
\hline Papum Pare & $2-3$ & $35-45$ \\
\hline Lower Subansiri & $3-4$ & $45-55$ \\
\hline Upper Subansiri & $2-3$ & $30-40$ \\
\cline { 2 - 3 } & $3-4$ & $40-50$ \\
\hline West Siang & $2-3$ & $35-45$ \\
\hline Upper Siang & $3-4$ & $45-55$ \\
\hline East Siang & $2-3$ & $20-30$ \\
\hline & $2-4$ & $30-40$ \\
\hline
\end{tabular}

Source: Field Survey (December 2011).

6. High profit margin: Selling of Mithun meat is found to be very profitable. During the course of study it was found that market price of Mithun meat per kilogram ranges from Rs 150 to Rs 300 in the study districts. It can be seen from the Table 2 that market priced of Mithun is highest in Papum Pare district with Rs 300 per Kg and lowest in East Siang District with Rs 150. However, it may be noted that selling of Mithun meat in the local market is very rare in case of Lower Subansiri, West Siang, Upper Siang and East Siang.

Table 2 Showing selling price per $\mathrm{k} / \mathrm{gm}$ of Mithun meat in the selected districts (data as on 28.12.11)

\begin{tabular}{|lll|}
\hline \multirow{2}{*}{ Name of District } & $\begin{array}{l}\text { Mithun } \\
\text { meat }\end{array}$ & $\begin{array}{l}\text { Selling Price per K/gm (in '00 } \\
\text { rupee) }\end{array}$ \\
\cline { 2 - 3 } & Flesh & $\mathbf{3 0 0}$ \\
\cline { 2 - 3 } & Flesh with bone & 250 \\
\hline \multirow{2}{*}{ Lower Subansiri } & Flesh & n.a \\
\cline { 2 - 3 } & Flesh with bone & n.a \\
\hline \multirow{2}{*}{ Upper Subansiri } & Flesh & --- \\
\cline { 2 - 3 } & Flesh with bone & 200 \\
\hline West Siang & Flesh & 200 \\
\cline { 2 - 3 } & Flesh with bone & 150 \\
\hline Upper Siang & Flesh & n.a \\
\cline { 2 - 3 } & Flesh with bone & n.a \\
\hline East Siang & Flesh & 200 \\
\cline { 2 - 3 } & Flesh with bone & 150 \\
\hline
\end{tabular}

Source: Field Survey (December 2011). 
Commoditisation And Sustainable Management Of Mithun (Bos Frontalis) In Arunachal Pradesh,

Besides, in a study carried out in the twin capital of Arunachal Pradesh i.e. Itanagar and Naharlagun, selling of Mithun meat in the market was found to be highly profitable, it can be observed from the Table 3 that benefits yields from Mithun costing Rs 35,000, Rs 45,000 and Rs 55,000 is more than 60 percent.

Table 3 Showing the Cost-benefits ratio of Mithun costing Rs 35,000, Rs 45,000 and Rs 55,000 in Itanagar/Naharlagun (as on 06.01.12)

\begin{tabular}{|l|r|r|r|}
\hline Cost of adult Mithun & Rs 35,000 & Rs. 45,000 & Rs. 55,000 \\
\hline Average weight (flesh with bones) & $240 \mathrm{~kg}$ & $300 \mathrm{~kg}$ & $350 \mathrm{~kg}$ \\
\hline Selling price per kg & Rs 250 & Rs 250 & Rs 250 \\
\hline Total sales proceeds (gross) & Rs.60,000 & Rs. 75,000 & Rs. 87,500 \\
\hline Less: $10 \%$ overheads & Rs. 6,000 & Rs. 7,500 & Rs. 8,750 \\
\hline Total sales Proceeds (net) & Rs.54,000 & Rs. 67,500 & Rs. 78,750 \\
\hline Cost-benefit ratio & $\mathbf{0 . 6 4}$ & $\mathbf{. 6 6}$ & $\mathbf{. 6 9}$ \\
\hline
\end{tabular}

Source: Field Survey (January 2012).

7. Demonstration effect: In the course of discussion with village elders during survey it was observed that, in a developing tribal economy people are easily lured by money. Since, selling of Mithuns/Mithun meat is profitable venture; it easily attracts others also to follow the practices of selling Mithuns/Mithun meat. This attitude of the people has also contributed to a great extent in commercialising the mithuns.

8. Mithun itself is a brand: Blended with pride, status, values, taste and preference; the name 'Mithun' itself is brand in the state of Arunachal Pradesh. This has led to more demand of Mithun especially in social occasions like festivals, marriage etc,. It is observed that there is close association between branding and commercialising. These states of affairs have greatly contributed in commercialisation of Mithun in the state.

\section{Mithun: Future Commercial Perspective}

Considering the commercial potentialities of Mithuns, it is expected that demand of Mithuns in the market will increase in the near future. Besides Mithun meat; milk, hides and skin of Mithun also possess lots of commercial value. Though the consumption of the Mithun milk is not a routine practice among the tribal people however; Mithun produces around 1-1.5 kg milk/ day / animal (Nath and Verma, 2000). It contains $3.4-17$ per cent of fat, 6.8-22.2 per cent SNF and 4.4-9.8 per cent protein. Hence, Mithun milk is superior from nutrition point of view compare to other cattle and posses lots of scope for preparation of different delicious milk products (Annual report, 2003-04). Besides, Mithun hide and skin is of very good quality than other cattle leather having more value in tanning industry due to its toughness and longevity, therefore utilized for the production of goods like shoes, garments, bags, jackets, purses, attractive ornamental things and furniture covers etc. expensive leather products can be prepared out of the processed hides and it can also fetch good price in national and international market (Mukjherhee 2007).

\section{Mithun: Sustainability Issues}

Considering the prevailing scenario of indiscriminate slaughtering of Mithun, declining feed or fodder resources, in-adequate Mithun health coverage and rampant in-breeding as well as to foster better commercial flatform for Mithun; there is a need to conserve, sustain and develop the growth of Mithun in the state. In this respect the following measures are advocated to address the problems for sustainable growth and development of Mithuns (Taba Heli).

1. Need for conservation of natural habitat of Mithuns: The natural forest areas along with protection of deforestation especially "Shifting cultivation practices" in the catchments of the natural streams or salt-lick sources for Mithuns be banned or minimized. There a need to create mass awareness among the rural and urban dwellers on forest conservation to check environmental degradation.

2. Need for cultivation of natural fodders commonly relished: The natural fodders commonly relished by Mithuns needs to be identified, analyzed for chemical compositions. Such fodders with high nutrient content be developed in the fodder nurseries and cultivated in the fodder plots for the buffer stocks of fodders.

3. Improving the breeding problems: The breeding problems can be improved by restricting the sale or slaughter of the breeding bulls and retaining in the same herd for maximum 4 years after which it may be replaced or exchanged with other herds. The in-breeding problems can be checked by castrating the scrub bulls in the population. Moreover, the indiscriminate slaughter or sale of productive Mithuns in the festive occasions, marriage ceremony or for the commercial purpose be banned through appropriate law to minimize the slaughter of the Mithuns. 
Commoditisation And Sustainable Management Of Mithun (Bos Frontalis) In Arunachal Pradesh,

4. Adequate Mithun Health coverage: The compulsory Mithun health camps in different areas for routine deworming, disease diagnosis \& treatment and scheduled vaccination programmes against the infectious diseases will check the morbidity and mortality of Mithuns thereby improving their productivity.

5. Conservation of the biodiversity in the area: Under the free-range management, the Mithuns destroy the agricultural crops. By ear marking the Mithun grazing area like 'Lura' system, the habitat area of Mithun will be conserved thereby, natural forest (natural flora and fauna ) of the whole area can be conserved by restricting the tress-passers in the Mithun rearing area.

6. Community mobilization for participatory approach: The success of the community project on Mithuns will depend on involvement of the community in the plan and programme of the project. The mass awareness programme on need for conservation of the natural habitat of Mithuns through the public meeting involving the village elders and Mithun owners will be envisaged. All the Mithun owners will be motivated to form themselves into 'Mithun club' and guided them to generate their own resources of by mobilizing savings and sense of belongingness. The farmers would contribute monthly or quarterly to the common pool and it would be kept in the bank to check any misuse. It would help farmers to maintain the structure at the time of need and even after the completion of project period for its sustainability. Further, proper training to build up capacity on Mithun husbandry, Mithun health by qualified trainers is need for sustainable development of Mithuns.

7. Last but not the least; Arunachal Pradesh being the home of highest number of Mithuns in the country accompanied by suitable vast and natural vegetation, establishment of Research Centre specifically for Mithuns is very much sought in the state for documentation, scientific investigation, research and development etc., on Mithun.

\section{Conclusion}

Mithun being the endemic species and heavily built massive animal which is found only in the few states of the North-Eastern Region of Indian union demands the timely care and attention at all levels. Over the years the uses of Mithuns are more of commercial then cultural purposes. Hence, there is an urgent need to conserve this rare animal genetic resource of the Indian origin through the appropriate conservation programmes at the Government level. The need of the hour is to inculcate the Mithun rearers with suitable package of practices or the scientific innovative and to exploit its inbuilt potentials of Milk, meat and work power in the hilly state of Arunachal Pradesh in Particular and North-Eastern States in general where the Mithun stands as the majestically pride animal.

[1] Livestock census, 2007, India.

\section{References}

[2] Annual Report of National Research Center on Mithun, Medzipema, Nagaland (2003-2004).

[3] M.G. Shisode, A.V. Khanvilkar, M.D. Kulkarni, S.R. Samant, G.B.Yadav and M.S. Bawaskar (2009): "Mithun : The Pride animal of North-eastern hilly region of India", Veterinary World Vol.2 (12).

[4] K C Das, G Mukherjee*, K K Baruah, K Khate and C Rajkhowa (2011): "Study of growth performance and leather quality in mithun (Bos frontalis) and its comparison with local cattle (Bos indicus) fed on tree leaves based ration”, Livestock Research For Rural development, Vol 23 (5), Columbia.

[5] Taba Heli: “Sustainable Management of Mithuns in Arunachal Pradesh”, paper unpublished, KVK, Papum Pare, Itanagar. 